\title{
Additive Manufacturing and Synthetic Polymers for Bone Reconstruction in the Maxillofacial Region
}

\begin{abstract}
CORINA MARILENA CRISTACHE ${ }^{1}$, ALEXANDRA RALUCA GRO SU², GHEORGHE CRISTACHE ${ }^{3}$, ANDREEA CRISTIANA DIDILESCU4, EUGENIA EFTIMIE TOTU2*

'University of Medicine and Pharmacy Carol Davila, Faculty of Midwifery and Medical Assisting (FMAM), Department of Dental Techniques, 8 Eroilor Sanitari Blvd., 050474, Bucharest, Romania

2University Politehnica of Bucharest,Faculty of Applied Chemistry and Material Science, 1-5 Polizu Str, 11061 Bucharest, Romania ${ }^{3}$ Concordia Dent Clinic, 7D-7E Vitan-Barzesti Str., 042121, Bucharest, Romania

${ }^{4}$ University of Medicine and Pharmacy Carol Davila, Faculty of Dental Medicine, Department of Embryology, 37 Dionisie Lupu, 020021, Bucharest, Romania

The aim of the present paper is to give an up-to date on computer aided design and manufacturing (CAD/ CAM) additive techniques and synthetic polymers for bone reconstruction in the maxillofacial region. Additive manufacturing represents a promising field for future research in bone replacement/regeneration. However, standard guidelines for mimicking clinical environment with the different bone characteristics are strongly required. The rapid prototyping techniques, particularly, bioprinting allows the construct of $3 D$ living functional tissues able to replace, in the near future, large defects caused by tumor excision, trauma, clefts or infections, limiting the autogenous bone graft requirement.
\end{abstract}

Keywords: synthetic polymers, bone graft, maxillofacial region, biomolecules, additive manufacturing

Reconstruction of maxillofacial bone defects has always been a challenging task for the scientists and surgeons over the years, with the main goal to restore facial form, masticatory and phonetic functions, full esthetic and improve quality of life [1]. When bone defect is relatively small, regeneration by intrinsic mechanism from surrounding tissues may occur [2,3]. Bone is known to be the second most commonly transplanted tissue after blood [4].

Natural bone is a dynamic organ with outstanding regenerative properties, its homeostasis requiring viable cells (osteoblasts, osteoclasts, and osteocytes), adequate vascularity, stability, as well as presence of growth factors and a matrix for growth [5].

Currently, autologous bone graft from intraoral (tuberosity, chin, mandibular ramus) or extraoral donor sites (iliac crest, tibia, calvaria, and many others) is considered as the gold standard among all bone grafts $[4,6,7]$. Nevertheless, autogenous grafting has several limitations related to the bone volume requested (e.g. for craniofacial defects reconstruction) and the harvesting process.

Synthetic bone substitutes [8], mostly made of hydroxyapatite $(\mathrm{HA}), \mathrm{Ca}_{10}\left(\mathrm{PO}_{4}\right)_{6}(\mathrm{OH})_{2}$ or $\beta$-tricalcium phosphate ( $\beta-\mathrm{TCP}, \mathrm{Ca}_{3}\left(\mathrm{PO}_{4}\right)_{2}$ with rhombohedral structure) [3], are an osteoconductive alternative to both autologous and allogenic graft options, with wide availability, comparatively low cost and absence of risks such as donor site morbidity and viral transmission [9], butusually lacking of osteogenic or osteoinductive activity [10-12].

Recently, with the development of tissue engineering (TE) as previously defined 'an interdisciplinary field of research that applies the principles of engineering and the life sciences towards the development of biological substitutes that restore, maintain, or improve tissue function' [13], a new era of bone substitute materials raised. In contrast to classic biomaterials approach, it is based on the understanding of tissue formation and regeneration, and aims to induce new functional tissues, rather than just to implant biocompatible spare parts [14].

To date, two main types of bone scaffolding manufacturing technologies are described: the first one is usually referred to as conventional technology, including: solvent casting, solvent/particulate leaching [15], freezedrying, thermally induced phase separation (TIPS), gas foaming/supercritical fluid processing, electrospinning, powder-forming process, or sol-gel technique [16] and the second type of technologies is referred to as Rapid Prototyping (RP), which involves computer-aided design (CAD) and manufacturing (CAM).

The conventional technology has several drawbacks, mainly concerning the lack of reproducibility of pore structure (size, geometry, spatial distribution) and the persistence of solvent and porogens residues leading to host tissue inflammatory response.

The CAD/CAM technology, extendedly used nowadays in dental practice $[17,18]$, is envisaged as an opportunity to overcome the challenges in biomimetic bone substitutes fabrication for the maxillofacial region.

The natural bone matrix is composed of biological ceramics ( $70 \%$ in weight), the inorganic part formed mainly by hydroxyapatite and of biological polymers (30\% in weight), the organic matter, which is primarily collagen type I and ground substance [16]. For bone substitute, several naturally derived biopolymers have been used, such as collagen, demineralized ectodermal-degenerated proteins (i.e. gelatine), and chitosan with good results due to excellent biocompatibility, biodegradability and cellbinding properties but with major drawbacks mainly consisting in immunogenicity, rapid degradation, and poor mechanical properties [19]. To overcome this drawbacks, attention has been paid to biocompatible and biodegradable synthetic polymers with a considerable number of advantages such as controllable degradation rate, predictable and reproducible mechanical properties, sterilization ability, and ease of fabrication with tailorable shapes and sizes, as required for the bone defect need to be replaced [20].

*email: eugenia_totu@yahoo.com 
The aim of the present paper was to give an up-to date on CAD/CAM additive techniques and synthetic polymer materials for ideal bone reconstruction in the maxillofacial region.

\section{Experimental part}

An extensive review of the recent literature focusing on the mechanisms of bone repair, mechanical characteristics of maxillofacial bone, characteristics of an ideal bone substitute, bone graft design, additive manufacturing technologies and synthetic polymers have been performed. The following databases: Pubmed, Summon database ProQuest, Embase, Cochrane have been assessed for articles in English language, from 2000 to date. A manual search in Dental Materials, J ournal of Dentistry, J ournal of Cranio-Maxillofacial Surgery, Revista de Chimie, J ournal of Materials, Revista de Materiale Plastice and Acta Biomaterialia, has been also performed.

\section{Results and discussions}

Bone repair: Requirements for an ideal bone substitute

Bone repair has been classified into three distinct phases: inflammatory, proliferative, and remodeling [21]. The result of the inflammatory phase is the primitive callus formation followed by its organization during the proliferative phase. The resulted immature woven bone is then converted into lamellar bone by replacement of the mineralized callus with mature mineralized bone and remodeling of the area of bone, back to its original shape and size [5] (fig. 1).

A bone engineering construct relies on a combination of living cells, biologically active molecules and a structural scaffold in order to promote the repair and regeneration of tissues [22].

The scaffold component plays an important role, being expected to support cell colonization, migration, growth and differentiation, so that it guides the development of the required tissue and, in the meantime, provides sufficient initial mechanical strength and stiffness to substitute for the mechanical function of the diseased or damaged bone to be replaced [22]. It acts as a temporary matrix for cell proliferation and extracellular matrix deposition, with consequent bone ingrowths until the new bony tissue is totally restored/regenerated $[14,23,24]$.

Bone scaffolds are typically made of porous degradable materials providing the mechanical support during repair and regeneration of damaged or diseased bone and serving as a reservoir of progenitor cells, water, nutrients, cytokines, and growth factors [25].

The following properties for bone substitutes are required, depending on the etiology of bone loss, as well as volume, structure, size and localization of the structure to be replaced:
Biocompatibility, described as the ability to support normal cellular activity including molecular signaling systems without any local or systematic toxic effects to the host tissue [26], is an essential requirement of any bone scaffold. Scaffolds are also used to deliver biomolecules facilitating new bone formation.

Osteoconductivity is the process of osteogenic cells migration to the surface of the scaffold into the fibrin cloth, established right after the material implantation [27]. Microscopically, scaffolds should have similar structure to cancellous bone [28]. An ideal bone scaffold mustfacilitate bone cells to adhere, proliferate and form extracellular matrix (ECM) on its surface and pores. Osteoinductivity is the process of simulating the osteogenic differentiation pathway [29] upon recruiting stem and osteoprogenitor cells to a bone healing site.

Bioresorbability is the ability of an ideal scaffold to degrade with time in vivo, preferably at a controlled resorption rate, creating space for the new bone tissue ingrow ths [26]. The degradation behavior of the scaffolds should vary based on site specific characteristics. Ideally, by the time the injury site is totally regenerated, the scaffold should be totally degraded $[13,20,30]$.

Angiogenesis in bone scaffolds: In vivo conditions, supply of oxygen and nutrients is essential for the survival of growing cells and tissues within scaffolds [31]. The inflammatory wound healing response induces spontaneous vascularization after scaffold implantation; however, it takes weeks to form a complex network of blood vessels. Osteoconductive or osteoinductive bone scaffolds do not induce vascularization. Moreover, improper and insufficient vascularization leads to oxygen and nutrient deficiency, which may result in non-uniform cell differentiation and cell death [32]. Specific biomolecules, such as vascular endothelial growth factor (VEGF) can be used to induce a complex network of blood vessels throughout a scaffold [33-36].

The mechanical properties of the implanted graft should ideally match, in vivo, those of living surrounding bone, so that an early mobilization/functionalization of the injured site can be made possible $[24,37,38]$.

There are two types of bone structures, classified according to their porosity, structure and metabolic activity: cortical bone, which is dense solid material $(>3 \mathrm{~mm})$, organized osteons $(10-500 \mu \mathrm{m})$, lamellae $(3-20 \mu \mathrm{m})$ and collagen mineral composite $(60-600 \mathrm{~nm})[39,40]$ and cancellous bone, which is highly porous, consisting of solid material (>3 mm), trabeculae (75-200 $\mu \mathrm{m})$, lamellae (1$20 \mu \mathrm{m})$ and collagen-mineral composite $(60-600 \mathrm{~nm})$ forming an interconnected network of trabeculae, usually filled with marrow [40,41]. Mechanical properties of bone vary widely from cancellous to cortical bone. Modulus of elasticity (Young's modulus), described as the ratio

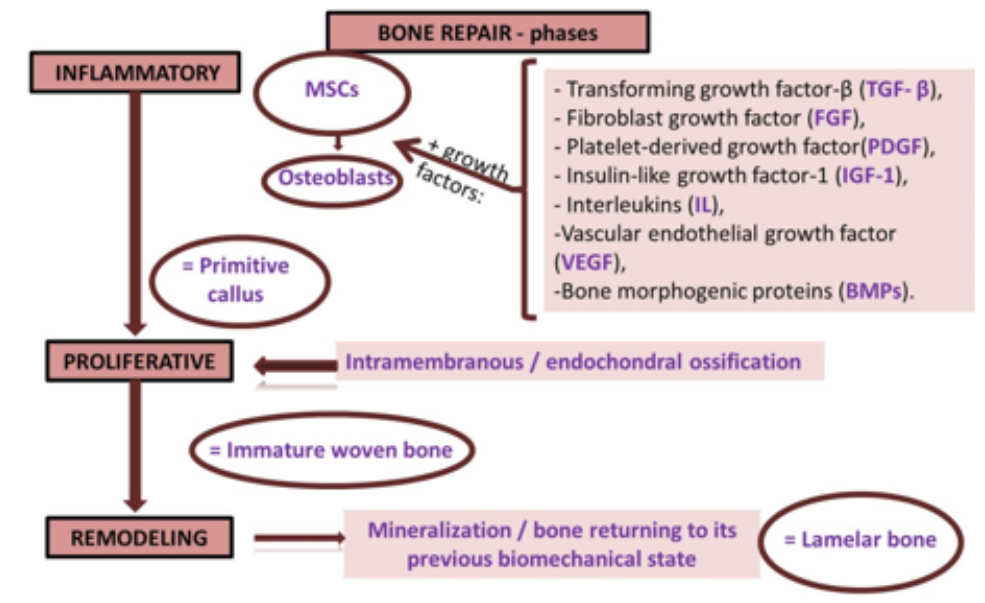

Fig.. 1. Bone repair phases $[3,5,21]$ 
between the stress applied and the resulting deformation in the material [42] of cortical bone is between 15 and 20 $\mathrm{GPa}$, while that of cancellous bone is between 0.1 and 2 $\mathrm{GPa}$. Compressive strength varies between 100 and 200 $\mathrm{MPa}$ for cortical bone, and between 2 and $20 \mathrm{MPa}$ for cancellous bone [30].

Architecture: Scaffolds must possess a fully interconnected geometry involving both micro- and macroporosities [43], with large surface, allowing cells migration and neo-vascularization of the construct from the surrounding tissue [44].

For bone tissue engineering purposes, most of the researchers agreed with pore size within the 200-900 $\mu \mathrm{m}$ range [45-47]. Holy and co-workers [48] believed that bone reconstruction will only be achieved by having a 3D temporary matrix with a large macro-porous interconnected structure, with pore size ranging from 1200$2000 \mu \mathrm{m}$. This later approach has evident advantages due to its high surface to volume ratios that will facilitate cell, tissue and blood vessels in-growth, but being detrimental in mechanical resistance. Murphy and co-workers [49] found pore size in the range of 200 to $350 \mu \mathrm{m}$ to be optimal for bone tissue proliferation, allowing successful diffusion of essential nutrients and oxygen for cell survival and removal of metabolic waste resulting from the activity of the cells that had meanwhile grown into the scaffold. Karageorgiou and Kaplan [50] agreed with pore sizes greater than $300 \mu \mathrm{m}$ being required for adequate vascular ingrowth. However, if the pores employed are too small, pore occlusion by the cells will occur. According to Di Luca and coworkers [51], heterogeneous distribution of pore size enhances osteogenic potential. Nevertheless, it should always be a balance between mechanical needs and pore dimension of the particular tissue that is going to be replaced [25].

Scaffold structure should mimic the complex bone architecture needed to be replaced, therefore, a nonhomogeneous design requires to be reproduced [52]. Materials used as scaffolds for bone tissue regeneration need to promote the cells' adhesion [53], involved in stimulating signals that regulate cell differentiation, cell cycle, cell migration, and cell survival [54]. The affinity of cells to the implanted substrate is an important aspect to be considered in biomaterial design and development.

By including mesenchymal stem cells (MSCS), biomolecules, or adding functional nanoparticles, the characteristics of the bone scaffold could significantly be improved.

Cells: MSCs, first isolated in bone marrow [55] but also in blood, adipose tissue, trabecular bone, muscle and dermis [56] are multipotent cells, easy to isolate, relatively abundant and able to differentiate along chondrogenic, osteogenic, myogenic, and other mesenchymal pathways under appropriate inductions [22-24].

Nowadays, it is generally accepted that MSCs exhibit tissue specific functional biodiversity, which is mediated by a direct cell-to-cell communication associated with the activity of adhesion molecules, cytokines, growth factors and cell signaling pathways.

Biomolecules: Molecular control over bone regeneration follows very closely the developmental osteogenesis [57] and fracture healing. Biomolecules with potential therapeutic activities in promoting bone regeneration are proteins / growth factors with biological action and temporal expression during the healing cascade. Molecular promoters for bone regeneration are divided in three main categories [58]: the transforming grow th factor beta (TGF- ß) superfamily, pro-inflammatory cytokines, and angiogenic factors.

The TGF- $\beta$ superfamily consists of a large number of growth and differentiation factors, the most important members, in terms of bone regeneration, are likely the bone morphogenetic proteins (BMPs), osteoinductive by themselves (especially BMP-2,-6,-7, and -9) [59] making them attractive therapeutically for tissue engineering products. TGF- $\beta$, release by the platelets after initial blood clot formation, plays a role in the production of extracellular proteins for callus formation [60], also initiating the production of BMPs in osteoprogenitor cells while inhibiting osteoclast activation [61].

In the initiation of the repair phase of bone regeneration, macrophages secrete pro-inflammatory cytokines: interleukin-1 (IL-1), interleukin-6(IL-6), and tumor necrosis factor alpha (TNF- $\alpha$ ), with maxim expression in the first $24 \mathrm{~h}$ of bone healing $[61,62]$.

In the early stages of bone healing, platelets entrapped within the local hematoma release Platelet-derived growth factor (PDGF), and up-regulates VEGF, responsible of generating new blood vessels in the tissue. Despite of their important role in bone healing and new bone formation, angiogenic factors alone are not osteoinductive [62]

Many natural hormones (Melatonin), biodegradable polymers (Hyaluronic acid) or other bio-factors including $\beta$-glycerol phosphate, dexamethasone, alendronate, polydopamine, have been used [63] to facilitate bone regeneration in particular cases.

Melatonin ( $\mathrm{N}$-acetyl-5-methoxytryptamine) -figure 2, a natural hormone secreted mainly by the pineal gland during the night, is an important mediator in bone formation and mineralization by promoting osteoblast differentiation and activity [64] through MEK/ERK1/2, runt-related transcription factor 2 (RUNX-2), osteocalcin [65], BMP-2 [66], BMP-4 [64], and Wnt [64] signal transduction pathways and by regulating the balance of bone remodeling through osteoclast activity suppression via increase in osteoprotegerin (OPG) and actions on receptor activator of NF-kB ligand (RANKL) [67].

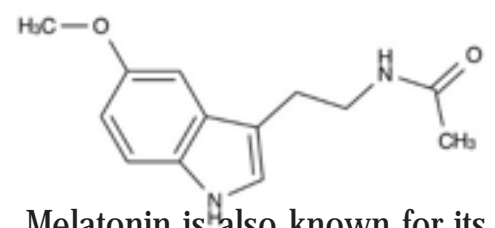

Fig. 2. Melatonin structure

Melatonin is also known for its antioxidant properties [68], reducing oxidative damage by directly scavenging free radicals and thereby protects cells from proinflammatory cytokines [69] and exhibits anti-angiogenic effects on endothelial cells $[70,71]$.

Recently, in an in vitro study, He and coworkers [72] found thatmelatonin bound to decellularized ECM improves the differentiation of human bone marrow (BM) MSCsinto osteoblasts and suppress the levels of matrix metalloproteinase genes (MMPs), with role in bone resorption, thereby preventing degradation of the calcified matrix.

Hyaluronic acid (Hyaluronan, HyA) -Figure 3, a linear anionic nonsulfated glycosaminiglycan composed by the repetition of a disaccharide unit of an $\mathrm{N}$-acetyl-glucosamine and a $\beta$-glucuronic acid, with negative charge, viscoelastic properties and high hidratation ratio, plays an important role in the control of tissue hydration $[73,74]$, stimulating bone wound healing.

HyA is a highly attractive natural biomaterial also due to its participation in cell behavior and cell signaling, widely distributed throughout connective, epithelial, and neural 


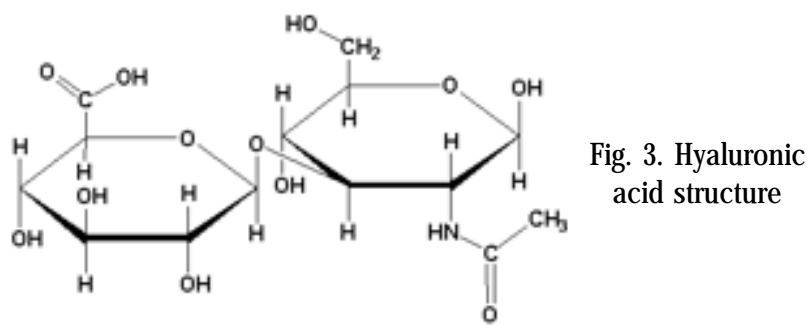

tissues. According to Selvin and coworkers, low-molecularweight HyA (LMW-HyA) enhances angiogenesis and increases collagen production by endothelial cells as compared to high-molecular-weight HyA with inhibitor effect on angiogenesis [ 75].

Recently, the results of several studies performed on animal models reveled promising results with the addition of HyA $[74,76]$, being incorporated in hydroxyapatite/betatricalcium phosphate (HA- $\beta$ TCP) [76], or biphasic calcium phosphate (BCP) ceramic $[74,77]$.

Alendronate, part of bisphosphonate family, was previously used [76], in a rat model, released through Polycaprolactone (PCL)-coated 3D printed porous TCP scaffold, for its potential inhibition of bone resorption.

$\mathrm{Ma}$ and cow orkers fabricated a bi-functional scaffold from 3D-printed bioceramic covered with a uniformly selfassembled nanostructured Ca-P/polydopamine surface with proved tumor cell death induction in vitro and remarkable capability for both cancer therapy (osteosarcoma cells and breast cancer cells) and bone regeneration, in vivo, on mice model [78].

Functionalized Nanoparticles, including functionalized ferroferric magnetic nanoparticles, may be suitable for numerous potential uses such as improvement of tissue regeneration, enhancing implants osseointegration, and the prevention of infections [78]. Three main directions were envisaged for the usage of nanoparticles in bone regeneration/remodeling: cell labeling, to assess the regenerative therapy; controlled, sustained drug delivery, according to requirements, of adequate tuned nanoparticles; and more advanced, for a longer therapeutic effect, gene delivery [ 79].

\section{CAD/CAM for bone grafting in the maxillofacial region}

Bone graft design: Radiological images, such as those derived from X-ray cone beam computed tomography (CBCT) - for maxillofacial region, medical computed tomography (MDCT) or magnetic resonance (MR) scanners, provide excellent sources for $3 \mathrm{D}$ anatomical data acquisition [80-82] for graft design and scaffold tissue engineering [81,83-86].

Additive manufacturing requires the conversion of $\mathrm{CBCT}$ files, commonly saved as DICOM (Digital Imaging and Communication in Medicine) files into STL (standard tessellation language). The DICOM to STL conversion involves a segmentation of voxels into different tissues types according to the gray scale, performed, most commonly to date, by manual or default thresholding [87]. DICOM to STL conversion is often a potential source of error [88]. However, despite of the large existing number of automatic tissue identification algorithms, for the complex anatomical maxillofacial region and/or the presence of artefacts (metallic crowns, bridges), manual segmentation or a combination of automated and manual segmentation are often required for increasing accuracy $[88,89]$.

In order to improve accuracy, future research should focus on developing new medical image segmentation software that is suitable for different CT imaging modalities [87].

Rapid Prototyping (RP) technology and polymeric materials for bone substitutes: To adequate replace a biological structure, with appropriate shape and tissue forming characteristics, the rapid prototyped bone replacement can be obtained either by printing acellular scaffold that can be eventually populated with cells or biomolecules prior to implantation, or directly printing a living cellular construct, namely bioprinting [90]. In the first approach, scaffolds, from either natural or synthetic materials, provide the appropriated biomechanical environment to allow cells to produce their own extracellular matrix. In the second approach, specific additive manufacturing techniques are used to print cells immobilized within polymeric hydrogels producing cellladen three-3D constructs [91].

$R P$ techniques (additive manufacturingor solid free form fabrication) for a cellular scaffold, recently introduced with the aim of overcoming the limitations of standard technologies, are additive fabrication processes that manufacture the final 3D object, based on a CAD design file, by deposition layer-by-layer, with the use of liquid-, solid-, and powder-based materials [92]. The general steps of the RP technique are presented in figure 4 . Among the

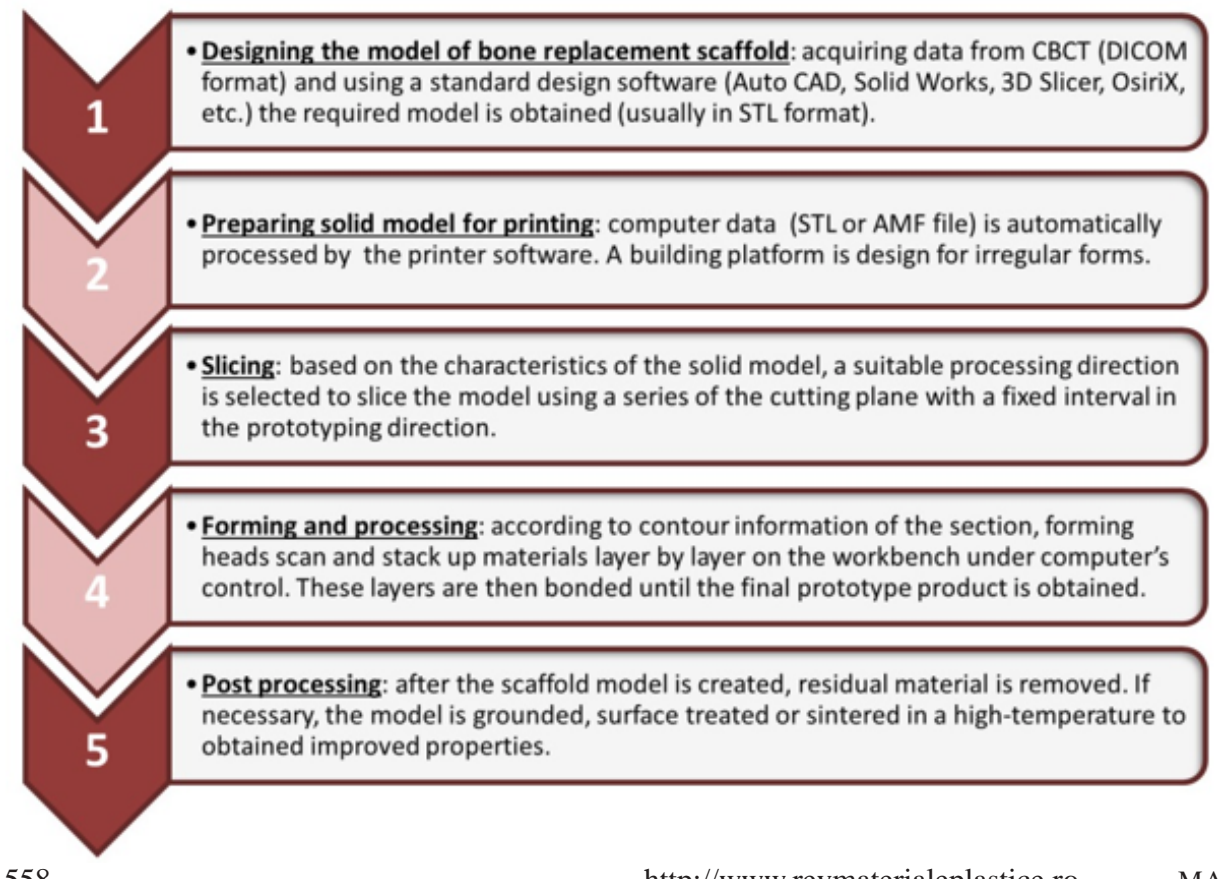

Fig. 4. Steps in Rapid prototyping. $[92,93,95]$. Digital Imaging and

Communications in Medicine (DICOM), Stereolithography File Format (STL), Additive Manufacturing File Format (AMF) 


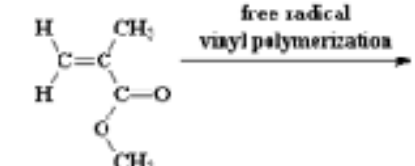

$\mathrm{CH}_{1}$

methyl methacrylate

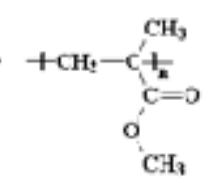

poly(nethyl nechearylate)

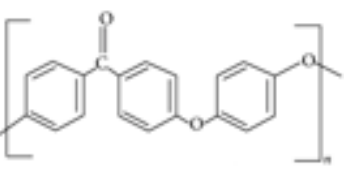

Fig. 6. PEEK structure

Fig. 5. a. Poly (methyl methacrylate) synthesis; b. Micro-CT image of 3D printed PMMA

RP techniques, Stereolithography (SLA), Fused Deposition Modeling (FDM), Selective Laser Sintering (SLS) and Inkjet printing are mostly used in the last years for synthetic polymers bone scaffold manufacturing [92,93].

$S L A$ is based on the use of a UV laser that is vector scanned over the top of a bath of a photo-polymerizable liquid material. As polymerization is initiated, the laser beam creates a first solid layer, just below the surface of the bath. This laser polymerization process is repeated to generate subsequent layers by tracing the laser beam along the design boundaries and filling in the $2 \mathrm{D}$ cross-section of the model, layer-by-layer. Once the model is complete, the platform is raised out of the bath and the excess resin is drained.

The materials suitable for SLA need to be photo crosslinked by ultraviolet or visible light according to a sliced CAD model.

FDM is the process by which a thermoplastic material is melted in a heated head [94] and extruded through a small orifice onto a stage layer. The deposited material fuses to the previous laid layer and generates a scaffold a layer-bylayer fashion [96].

SLS uses a $\mathrm{CO}_{2}$ or Nd:YAG laser beam to sinter selected regions of material pow ders onto a powder bed surface, forming a material layer. Once a first layer is solidified, the powder bed is lowered by one-layer thickness. The next layer of the material is laid down on the top of the bed by a roller. The process is repeated until the scaffold is completed $[16,96]$.

Inkjet printing (3D printing or Binder-s et) A liquid binder is sprayed onto the layer of the powder bed; this merges particles together to form a solid layer. The powder bed is then lowered so that a new powder layer is spread over the surface of the previous layer by the roller. This process is repeated until the designed object is obtained [16,97].

$3 \mathrm{D}$ bioprinting -technique is a fabrication technology used to precisely dispense cell-laden biomaterials for the construction of complex 3D functional living tissues [98], controlling cell proliferation, attachment, and migration within 3D structures [99]. Among the described RP methods, solely Inkjet printing enables fabrication of heterogeneous tissue constructs composed of deposited cells, growth factors, ECM molecules, pharmaceutical and biological agents, such as peptides, proteins (e.g. fibrinogen, collagen), polysaccharides (e.g. hyaluronic acid, alginate), or other biomaterials of interest [100,101], with no photo polymerization, no high temperatures, no extrusion, or laser-sintering requiring. To date, the most used bioprinting technologies are jetting-, extrusion-and laser- based printing $[98,102]$ with hydrogel as base material.

In the jetting-based (ink-jet/droplet-based) technique, picolitre bio-ink droplets (smaller than 30 im in diameter) are layered onto a substrate [103]. The extrusion-based bioprinting systems dispense continuous filaments of a material consisting of cells mixed with hydrogel through a micronozzle, using piston or pneumatic pressure to fabricate two dimensional (2D) or 3D structure. After printing 2D patterns, hydrogels are physically or chemically solidified and 3D structures are fabricated by stacking 3D patterns layer by layer. The laser-based bioprinting [104] uses the energy of pulsed laser focused on the absorbing gold layer of the ribbon and this generates a high-pressure bubble, which propels cell-containing materials towards the collector substrate [98].

Synthetic polymers as bone grafting materials

Poly (methyl methacrylate) (PMMA)- belonging to methacrylate esters large family and obtained from methyl methacrylate - Figure 5.a., offers similar strength as compared to native bone tissue, a remarkable plasticity, long-term durability, is easily manufactured, inexpensive, and produces no visible radiographical artifacts -Figure 5.b.

How ever, the residual monomers from polymerization can cause damage to human cells [123], and pore size may influence osteoconductivity and vascularization of the implanted graft, therefore, processing technology is of a great importance. Additive manufacturing allows control pore dimensions and reduces monomer leaching, therefore improving material's characteristics and biocompatibility [105-108]. In a systematic review and meta-analysis analyzing complications with the use of PMMA for cranioplasty, no difference was observed between the complication rates of PMMA and autologous bone or between PMMA and titanium mesh [123].

Polyetheretherketone (PEEK), Figure 6, is a chemically inert polymer, with structural stability at temperature greater than 300 degrees Celsius, allowing steam graft sterilization, with elastic properties similar to cortical bone, radiolucency and suitable for additive manufacturing (FDM technology).

When comparing PEEK grafts to autogenous bone and titanium mesh, Punchak and co-workers [123] found no statistically significant differences between the bone replacement for cranioplasty.

The synthetic biodegradable polymers with high biocompatibility most commonly used for bone tissue engineering are poly (glycolic acid) - PGA, poly(lactic acid) - PLA, poly(e-caprolactone) - PCL, poly(lactide-co-glycolic acid) - PLGA. They can be produced under controlled conditions and thus exhibit predictable and reproducible mechanical and physical properties such as tensile strength, elastic modulus, and degradation rate, by using various molecular weights, structure, composition, and copolymers and can be easily processed, being also suitable for all additive manufacturing technologies (SLA, FDM, SLS, Binder-J et).

Among elastomeric polymers poly(glycerol sebacate) (PGS) is extensively studied for use as scaffolding biomaterial in bone tissue regeneration due to its high biocompatibility [109]. It is synthesized through the polycondensation (esterification) reaction of tri-functional glycerol, $\mathrm{HOCH}_{2} \mathrm{CH}(\mathrm{OH}) \mathrm{CH}_{2} \mathrm{OH}$, and difunctional sebacic acid $(\mathrm{HOOC})\left(\mathrm{CH}_{2}\right)_{3}(\mathrm{COOH})^{2}$ - figure 7.

The mechanical characteristics - Young's modulus of PGS is in the range of $0.056-1.2 \mathrm{MPa}$, and its elongation at 
<smiles>OCC(O)CO</smiles>

Glycerol
Sebacic Acid

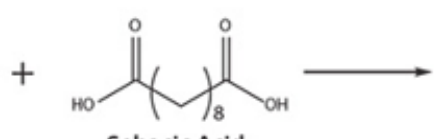

break ranges trom 41 to $448 \%$, depending on the synthesis conditions - and the rapid degradation, limits the application as bone substitute. To overcome these limitations, PGS was doped with Bioglass ${ }^{\circledR}$ filler, obtaining lower resorption rate and improved mechanical resistance [16].

Hydrogels, composed of a great variety of synthetic and natural polymers are three-dimensional, hydrophilic, polymeric netw orks able to retain large amounts of water, or biological fluids, without disintegrating. Their high content in water makes them similar to the living tissue. The suitability for bioprinting and the development of fundamentally new hydrogels, such as those formed by graphene oxide, could open up novel and more promising avenues towards the successful clinical use of composite hydrogels for bone regeneration.

\section{Conclusions}

Two main directions are envisaged for bone regeneration:

Developing scaffolds with mechanical strength, required to withstand the physiological loads seen in vivo, providing microenvironment to induce the desired cellular response and doping the scaffold with biomolecules able to stimulate migration and adhesion of autogenic blood MSCS.

Developing a bio-matrix including living cells, biomolecules, to replace the entire bone defect.

Despite of the great number of polymeric materials and various additive manufacturing techniques proposed in the reviewed studies, only a few have, to date, successful clinical applications, namely PMMA and PEEK. However, an ideal bone replacement have not been yet proposed due to the complex construction and characteristics of the bone living tissues.

Additive manufacturing technology represents a promising field for future research in bone grafting for maxillofacial region, butstandard guidelines for mimicking clinical environment with the different bone characteristics are strongly required.

Due to advanced technologies and materials, complex individual shapes can be reproduced nowadays with the desired porosity and geometry.

The rapid prototyping techniques, particularly, bioprinting allows the construct of $3 D$ living functional tissues able to replace, in the near future, large defect caused by tumor excision, trauma, clefts or infection, limiting the autogenous bone graft requirement.

Acknowledgement: This work was supported by a grant of the Romanian National Authority for Scientific Research and Innovation, CCCDI -UEFISCDI, project number 30/2016 (ERA-NET-MANUNET II) PRIDENTPRO within PNCDI III and partially supported by a grant of the Romanian National Authority for Scientific Research and Innovation, CCCDI - UEFISCDI, project number 39/2018 COFUNDMANUNET III-HAMELDENT, within PNCDI III. Authors kindly acknowledge the valuable help provided by George Vlasceanu and Stefan Voicu for running micro-CT analysis on 3D printed poly (methylmethacrylate).

\section{References}

1. ALFOTAWI, R., AYOUB, A., Am. J. Adv. Med. Sci., 2, 2014, p.18. 2. HIKITA, A., CHUNG, U., HOSHI, K., TAKATO, T., Tissue Eng. Part A, 23, 2017, p.515.
Fig. 7. Poly (glycerol sebacate) synthesis
Poly(glycerol sebacate)

3. UKYAN, A., ALIUADI, ১., MOSHIRI, A., MAFFULLI, N., J. Orthop. Surg. Res., 9, 2014, p.18.

4. ELSALANTY, M. E., GENECOV, D. G., Craniomaxillofacial Trauma Reconstr., 2, 2009, p.125.

5. FILLINGHAM, Y., JACOBS, J., Bone Jt. J, 98, 2016, p.6.

6. KINACI, A., NEUHAUS, V., RING, D. C., Orthopedics 37, 2014, p.e783.

7. NIMIGEAN, V., POLL, A., NIMIGEAN, V. R., MORARU, S. A., BADITA,

D. G., PAUN, D. L., Rev. Chim. (Bucharest), 69, no.5, 2018, p. 1106.

8. ARPAD, S., TRAMBITAS, C., MATEI, E., VASILE, E., PAL, F., ANTONIAC, I. V., VOICU, S. I., BATAGA, T., FODOR, R., Rev. Chim. (Bucharest), 69, no.2, 2018, p.429.

9. FLYNN, J. M., OKU 10 Orthop. Knowl. Updat., 2011, p.11.

10.GREENWALD, A. S., BODEN, S. D., GOLDBERG, V. M., KHAN, Y., LAURENCIN, C. T., ROSIER, R. N., JBJS, 83, 2001, p.S98.

11.POPESCU, E., FORNA, D. A., EARAR, K., FORNA, N. C., Mat. Plast., 54, no.2, 2017, p.390.

12.FORNA, D. A., FORNA, N. C., EARAR, K., POPESCU, E., Mat. Plast. 54, no.2, 2017, p.312.

13.VACANTI, J. P., LANGER, R., Lancet, 354, 1999, p.S32.

14.KNESER, U., SCHAEFER, D. J., MUNDER, B., KLEMT, C., ANDREE, C., STARK, G. B., Minim. invasive Ther. allied Technol., 11, 2002, p.107.

15.NEMATI HAYATI, A., REZAIE, H. R., HOSSEINALIPOUR, S. M., Mat. Lett., 65, 2011, p.736.

16.THAVORNYUTIKARN, B., CHANTARAPANICH, N., SITTHISERIPRATIP, K., THOUAS, G. A., CHEN, Q., Prog. Biomater., 3, 2014, p.61.

17.CRISTACHE, C. M., IONESCU, C., CRISTACHE, G., IONESCU, I., ILIESCU, A. A., BURLIBASA, M., Metal. Int., 14, (SPEC. ISS.16), 2009, p.27.

18. CRISTACHE, C. M., IONESCU, C., BURLIBASA, M., CRISTACHE, G., ILIESCU, A. A., DUMITRIU, H. T., Metal. Int. 14, (SPEC. ISS.16), 2009, p.59.

19. FERREIRA, A. A. M., GENTILE, P., CHIONO, V., CIARDELLI, G., Acta Biomater., 8, 2012, p.3191.

20. LANZA, R., LANGER, R., VACANTI, J. P., Principles of tissue engineering, $4^{\text {th }}$ edition, Academic press, 2013.

21. ORYAN, A., MONAZZAH, S., BIGHAM-SADEGH, A., Biomed. Environ. Sci., 28, 2015, p.57.

22. HUTMACHER, D. W., SCHANTZ, J. T., LAM, C. X. F., TAN, K. C., LIM, T. C., J. Tissue Eng. Regen. Med., 1, 2007, p.245.

23. LAURENCIN, C. T., AMBROSIO, A. M. A., BORDEN, M. D., COOPER JR, J. A., Annu. Rev. Biomed. Eng., 1, 1999, p.19.

24. HUTMACHER, D. W., Biomaterials, 21,2000, p. 2529.

25. SALGADO, A. J., COUTINHO, O. P., REIS, R. L., Macromol. Biosci., 4, 2004, p.743.

26. WILLIAMS, D. F., Biomaterials, 29, 2008, p.2941.

27. DAVIES, J. E., Int. J. Prosthodont., 11, no.5, 1998,p. 391.

28. MCKEE, M. D., J. Am. Acad. Orthop. Surg., 14, 2006, p.S163.

29. ALBREKTSSON, T., JOHANSSON, C., Eur. Spine J., 10, 2001, p.S96. 30. BOSE, S., ROY, M., BANDYOPADHYAY, A., Trends Biotechnol., 30, 2012, p.546.

31. JAIN, R. K., AU, P., TAM, J., DUDA, D. G., FUKUMURA, D., Nat. Biotechnol., 23, 2005, p.821.

32. MALDA, J., ROUWKEMA, J., MARTENS, D. E., LE COMTE, E. P., KOOY, F. K., TRAMPER, J., VAN BLITTERSWIJK, C. A., RIESLE, J., Biotechnol. Bioeng., 86, 2004, p.9.

33. ROUW KEMA, J., RIVRON, N. C., VAN BLITTERSWIJK, C. A., Trends Biotechnol., 26, 2008, p.434.

34. CLARKIN, C. E., EMERY, R. J., PITSILLIDES, A. A., WHEELER J ONES, C. P. D., J. Cell. Physiol., 214, 2008, p.537.

35. WERNIKE, E., MONTJ OVENT, M. O., LIU, Y.; WISMEIJER, D., HUNZIKER, E. B., SIEBENROCK, K.-A., HOFSTETTER, W., KLENKE, F. M., Eur Cell Mater, 19, 2010, p.30. 
36. GARCIA, P., PIERUSCHKA, A., KLEIN, M., TAMI, A., HISTING, T., HOLSTEIN, J. H., SCHEUER, C., POHLEMANN, T., MENGER, M. D., J. Bone Jt. Surg., 94, 2012, p.49.

37. TAN, K. H., CHUA, C. K., LEONG, K. F., NAING, M. W., CHEAH, C. M., Proc. Inst. Mech. Eng. Part H J. Eng. Med., 219, 2005, p. 183.

38. LEONG, K. F., CHEAH, C. M., CHUA, C. K., Biomaterials, 24,2003, p.2363.

39. MARTIN, R. B., BURR, D. B., Am. J. Phys. Anthropol., 82, 1989, p.116.

40. POLO-CORRALES, L., LATORRE-ESTEVES, M., RAMIREZ-VICK, J. E., J. Nanosci. Nanotechnol., 14, 2014, p.15.

41. ZIOUPOS, P., CURREY, J. D., HAMER, A. J., J Biomed Mater Res, 45, 1999, p.108.

42. CECCARELLI, G., PRESTA, R., BENEDETTI, L., CUSELLA DE ANGELIS, M. G., LUPI, S. M., RODRIGUEZ Y BAENA, R., Stem Cells Int., 2017, PMCID: PMC5346390.

43. WOODARD, J. R., HILLDORE, A. J., LAN, S. K., PARK, C. J., MORGAN, A. W., EURELL, J. A. C., CLARK, S. G., WHEELER, M. B., JAMISON, R. D., JOHNSON, A. J. W., Biomaterials, 28, 2007, p.45.

44. SALGADO, A. J., GOMES, M. E., COUTINHO, O. P., REIS, R. L., Biopolym. Methods Tissue Eng., 2004, p.123.

45. YANG, S., LEONG, K. F., DU, Z., CHUA, C. K., Tissue Eng., 7, 2001, p.679.

46. MAQUET, V., JEROME, R., Design of macroporous biodegradable polymer scaffolds for cell transplantation, Materials Science Forum, Trans Tech Publ., Vol. 250, p. 15.

47. BURG, K. J. L., PORTER, S., KELLAM, J. F., Biomaterials, 21, 2000, p.2347.

48. HOLY, C. E., SHOICHET, M. S., DAVIES, J. E., J. Biomed. Mater. Res., 51, 2000, p.376.

49. MURPHY, C. M., HAUGH, M. G., O'BRIEN, F. J., Biomaterials, 31, 2010, p.461.

50. KARAGEORGIOU, V., KAPLAN, D., Biomaterials, 26, 2005, p.5474. 51. DI LUCA, A., OSTROWSKA, B., LORENZO-MOLDERO, I., LEPEDDA, A., SWIESZKOWSKI, W., VAN BLITTERSWIJK, C., MORONI, L., Acta Biomater., 36, 2016, p.210.

52. ATESOK, K., DORAL, M. N., KARLSSON, J., EGOL, K. A., JAZRAWI, L. M., COELHO, P. G., MARTINEZ, A., MATSUMOTO, T., OWENS, B. D., OCHI, M., HURWITZ, S. R., ATALA, A., FU, F. H., LU, H. H., RODEO, S. A., Knee Surgery, Sport. Traumatol. Arthrosc., 24,2016, p.2365.

53. KHALILI, A. A., AHMAD, M. R., Int. J. Mol. Sci., 16, 2015, p.18149. 54. HUANG, S., INGBER, D. E., Nat. Cell Biol., 1, 1999, p.E131.

55. OWEN, M., J. Cell Sci., Suppl. no.10, p.63.

56. CAPLAN, A. I., BRUDER, S. P., Trends Mol. Med., 7, 2001, p.259.

57. GILBERT SF., Developmental Biology. Osteogenesis: The Development of Bones, Dev. Biol., Sunderland (MA), 6th Ed., 2000.

58. AL-AQL, Z. S., ALAGL, A. S., GRAVES, D. T., GERSTENFELD, L. C., EINHORN, T. A., J. Dent. Res., 87, 2008, p.107.

59. TERMAAT, M. F., DEN BOER, F. C., BAKKER, F. C., PATKA, P., HAARMAN, H. J. T. M., J. Bone J oint Surg. Am., 87, 2005, p.1367.

60. LIND, M.; SCHUMACKER, B.; SOBALLE, K.; KELLER, J.; MELSEN, F.; BUNGER, C., Acta Orthop. Scand., 64, 1993, p.553.

61. DIMITRIOU, R., TSIRIDIS, E., CARR, I., SIMPSON, H., GIANNOUDIS, P. V., Injury, 37, 2006.

62. KOWALCZEW SKI, C. J., SAUL, J. M., Front. Pharmacol., 9, 2018.

63. LUO, Z., ZHANG, S., PAN, J., SHI, R., LIU, H., LYU, Y., HAN, X., LI, Y., YANG, Y., XU, Z., SUI, Y., LUO, E., ZHANG, Y., WEI, S., Biomaterials, 163,2018, p. 25.

64. PARK, K. H., KANG, J. W., LEE, E. M., KIM, J. S., RHEE, Y. H., KIM, M., JEONG, S. J., PARK, Y. G., HOON KIM, S., J. Pineal Res., 51, 2011, p.187.

65. ZHANG, L., SU, P., XU, C., CHEN, C., LIANG, A., DU, K., PENG, Y., HUANG, D., J. Pineal Res., 49, 2010, p.364.

66. SETHI, S., RADIO, N. M., KOTLARCZYK, M. P., CHEN, C. T., WEI, Y. H., J OCKERS, R., WITT-ENDERBY, P. A., J. Pineal Res., 49, 2010, p.222. 67. KOYAMA, H., NAKADE, O., TAKADA, Y., KAKU, T., LAU, K. H. W., J. Bone Miner. Res., 17, 2002, p.1219.
68. POEGGElER, B., REITER, R. J., TAN, D. X., CHEN, L. D., MANCHESTER, L. C., J. Pineal Res., 14, 1993, p.151.

69. LIU, X., GONG, Y., XIONG, K., YE, Y., XIONG, Y., ZHUANG, Z., LUO, Y., JIANG, Q., HE, F., J. Pineal Res., 55, 2013, p.14.

70. ALVAREZ-GARCIA, V., GONZALEZ, A., ALONSO-GONZALEZ, C., MARTINEZ-CAMPA, C., COS, S., Microvasc. Res., 87, 2013, p.25.

71. CRISTACHE, C. M., TOTU, E. E., PETRE, D., BUGA, R., CRISTACHE, G., TOTU, T., Rev. Chim. (Bucharest), 69, no.8, 2018, p.1996.

72. HE, F., LIU, X., XIONG, K., CHEN, S., ZHOU, L., CUI, W., PAN, G., LUO, Z. P., PEI, M., GONG, Y., J. Endocrinol., 223, 2014, p.167.

73. ROBERT, L., Pathol. Biol., 63, 2015, p.32.

74.DIKER, N., GULSEVER, S., KOROGLU, T., YILMAZ AKCAY, E., OGUZ, Y., J Craniofac Surg, 29, 2018, p. 1087.

75.SLEVIN, M.; KRUPINSKI, J., GAFFNEY, J., MATOU, S., WEST, D., DELISSER, H., SAVANI, R. C., KUMAR, S., Matrix Biol., 26, 2007, p.58. 76.CHANG, Y. L., LO, Y. J., FENG, S. W., HUANG, Y. C., TSAI, H. Y., LIN, C. T., FAN, K. H., HUANG, H. M., Biomed Res. Int., 2016, doi:10.1155/ 2016/8301624.

77. NGUYEN, T. B. L., LEE, B.-T., Tissue Eng. Part A, 20, 2014, p.1993. 78. TOTU, E. E., NECHIFOR, A. C., NECHIFOR, G., ABOUL-ENEIN, H. Y., CRISTACHE, C. M., J. Dent., 59, 2017, p. 68.

79. TAUTZENBERGER, A., KOVTUN, A., IGNATIUS, A., Int. J. Nanomedicine, 7, 2012, p. 4545.

80. RENGIER, F., MEHNDIRATTA, A., VON TENGG-KOBLIGK, H., ZECHMANN, C. M., UNTERHINNINGHOFEN, R., KAUCZOR, H. U., GIESEL, F. L., Int. J. Comput. Assist. Radiol. Surg., 5, 2010, p.335.

81. ESSES, S. J., BERMAN, P., BLOOM, A. I., SOSNA, J., Am. J. Roentgenol., 196, 2011, p.W683.

82. DONEY, E., KRUMDICK, L. A., DIENER, J. M., WATHEN, C. A., CHAPMAN, S. E., STAMILE, B., SCOTT, J. E., RAVOSA, M. J., VAN AVERMAETE, T., LEEVY, W. M., J. Vis. Exp., 22, no.73, 2013, p.e50250. 83. D'URSO, P. S., EFFENEY, D. J., EARWAKER, W. J., BARKER, T. M., REDMOND, M. J., THOMPSON, R. G., TOMLINSON, F. H., Br. J. Plast. Surg., 53, 2000, p.200.

84. LEUKERS, B., GULKAN, H., IRSEN, S. H., MILZ, S., TILLE, C., SCHIEKER, M., SEITZ, H., J. Mater. Sci. Mater. Med., 16, 2005, p.1121. 85. KHALYFA, A., VOGT, S., WEISSER, J., GRIMM, G., RECHTENBACH, A., MEYER, W., SCHNABELRAUCH, M., J. Mater. Sci. Mater. Med., 18, 2007, p.909.

86. SANDER, I. M., MCGOLDRICK, M. T., HELMS, M. N., BETTS, A., AVERMAETE, A., OWERS, E., DONEY, E., LIEPERT, T., NIEBUR, G., LIEPERT, D., Anat. Sci. Educ., 10, no.4, 2017, p.383.

87. VAN EIJ NATTEN, M., KOIVISTO, J., KARHU, K., FOROUZANFAR, T., WOLFF, J., Int. J. Comput. Assist. Radiol. Surg., 12, 2017, p.607.

88. HUOTILAINEN, E., JAANIMETS, R., VALASEK, J., MARCIAN, P., SALMI, M., TUOMI, J., MAKITIE, A., WOLFF, J., J. Cranio-Maxillofacial Surg., 42, no.5, 2014, p.e259.

89. CRISTACHE, C. M., Case Rep. Dent., 2017, doi:10.1155/2017/1096365. 90. NYBERG, E. L., FARRIS, A. L., HUNG, B. P., DIAS, M., GARCIA, J. R., DORAFSHAR, A. H., GRAYSON, W. L., Ann. Biomed. Eng., 45, 2017, p.45.

91. PEDDE, R. D., MIRANI, B., NAVAEI, A., STYAN, T., WONG, S., MEHRALI, M., THAKUR, A., MOHTARAM, N. K., BAYATI, A., DOLATSHAHIPIROUZ, A., NIKKHAH, M., WILLERTH, S. M., AKBARI, M., Adv. Mater., 29, no.19, 2017, p.1606061.

92. ROSETI, L., PARISI, V., PETRETTA, M., CAVALLO, C., DESANDO, G., BARTOLOTTI, I., GRIGOLO, B., Mater. Sci. Eng. C, 78, 2017, p.1246. 93.WEN, Y., XUN, S., HAOYE, M., BAICHUAN, S., PENG, C., XUEJIAN, L., KAIHONG, Z., XUAN, Y., JIANG, P., SHIBI, L., Biomater. Sci., 5, no.9, 2017, p.1690.

94.CHIA, H. N., WU, B. M., J. Biol. Eng., 9, 2015, doi:10.1186/s13036015-0001-4.

95.ALDAADAA, A., OWJI, N., KNOWLES, J., J Tissue Eng., 9, 2018, p.1. 96. BRACAGLIA, L. G., SMITH, B. T., WATSON, E., ARUMUGASAAMY, N., MIKOS, A. G., FISHER, J. P., Acta Biomater., 56, 2017, p.3.

97. FIELDING, G. A., BANDYOPADHYAY, A., BOSE, S., Dent. Mater., 28, 2012, p.113. 
98. MANDRYCKY, C., WANG, Z., KIM, K., KIM, D. H., Biotechnol. Adv., 34, 2016, p.422

99.MURPHY, S. V, ATALA, A., Nat. Biotechnol., 32, 2014, p.773.

100.0'BRIEN, C. M., HOLMES, B., FAUCETT, S., ZHANG, L. G., Tissue Eng. Part B Rev., 21, 2015, p.103.

101. JARIWALA, S. H., LEWIS, G. S., BUSHMAN, Z. J., ADAIR, J. H., DONAHUE, H. J., 3D Print. Addit. Manuf., 2, 2015, p.56.

102. OBREGON, F., VAQUETTE, C., IVANOVSKI, S., HUTMACHER, D. W., BERTASSONI, L. E., J. Dent. Res., 94, 2015, p.143S.

103. CUI, X., BOLAND, T., D'LIMA, D. D., LOTZ, M. K., Recent Pat. Drug Deliv. Formul., 6, 2012, p.149.

104. KERIQUEL, V., GUILLEMOT, F., ARNAULT, I., GUILLOTIN, B., MIRAUX, S., AMÉDÉE, J., FRICAIN, J. C., CATROS, S., Biofabrication, 2, 2010, p.014101.
105.TOTU, E. E., CRISTACHE, C. M., Rev. Chim.(Bucharest), 68, no. 9, 2017, p. 2102.

106. TOTU, E. E., VOICILA, E., PISTRITU, V., NECHIFOR, G., CRISTACHE, C. M., Rev. Chim.(Bucharest), 69, no.1, 2018, p. 155.

107. TOTU, E. E., CRISTACHE, C. M., VOICILA, E., OPREA, O., AGIR, I., TAVUKCUOGLU, 0., DIDILESCU, A. C., Mat. Plast., 54, no. 4, 2017, p.666.

108. TOTU, E. E., CRISTACHE, C. M., ISILDAK, I., YILDIRIM, R., BURLIBASA, M., NIGDE, M., BURLIBASA, L., Rev. Chim.(Bucharest), 69, no.5, 2018, p.1160.

109. WANG, Y., AMEER, G. A., SHEPPARD, B. J ., LANGER, R., Nat. Biotechnol., 20, 2002, p.602.

Manuscript received: 15.08 .2018 